História (São Paulo)

Traços biográficos de João Ribeiro ou as muitas faces de João

Viva a São João

João Ribeiro’s Biographical Traces or João's Many Faces

Rogério Rosa RODRIGUES*

Resumo: O artigo tem como proposta analisar a construção da imagem do intelectual João Ribeiro por meio das biografias elaboradas por pessoas próximas a ele. Buscou-se demonstrar o quanto tais trabalhos foram influenciados não apenas por questões afetivas, mas também por fatores ditados pelo tempo em que foram elaboradas. Com atenção às lacunas deixadas pelas biografias analisadas, constatou-se o esforço dos biógrafos em traçar um perfil intelectual de João Ribeiro, deixando de lado momentos marcantes de sua constituição como intelectual. Em suma, os autores se fixaram no momento em que Ribeiro já estava reconhecido no mundo das letras. A partir dessa constatação, optou-se por investigar o momento de fixação do autor na cidade do Rio de Janeiro e destacar as dificuldades enfrentadas para conquistar o espaço que o faria reconhecido, bem como suas opções políticas. Para este fim, recorreu-se a documentação pessoal do escritor, em especial, as correspondências enviadas a amigos como também as pistas encontradas nas obras de seus biógrafos.

Palavras-chave: João Ribeiro; biografia; historiografia.

Abstract: The aim of the article is to analyze the construction of the image of Brazilian author João Ribeiro as an intellectual by means of biographies written by people close to him. It was intended to show to what extent such works were influenced not only by affective issues, but also by factors closely related to the time in which they were written. Attending to the gaps left by the biographies under analysis, it was found that the biographers made an effort to build an intellectual profile of John Ribeiro leaving out key moments in the constitution of this writer as an intellectual. In short, Ribeiro's biographers focused precisely on the time he was already recognized in the Brazilian literary world. From that finding, the choice was to investigate the time the author settled down in the city of Rio de Janeiro, and to highlight the obstacles he faced to conquer the space that would make him recognized, as well as his political perspectives. For that matter, the writer's personal documentation was tackled, especially the mail exchanges with friends, and the clues found in the writings of his biographers.

Keywords: João Ribeiro; biography; historiography.

\footnotetext{
* Professor Doutor - Departamento de História da Universidade do Estado de Santa Catarina (UDESC) - Av. Madre Benvenuta, n. 2007, Bairro Itacorubi, Florianópolis, SC. CEP: 88.035-001. A pesquisa que resultou neste artigo contou com o financiamento do CNPq. E-mail: roger es@yahoo.com.
} 
De acordo com Humberto de Campos ${ }^{1}$, até 1933 o número de joãos santificados pela Igreja Católica chegava a 28. Somam-se a eles outros 12 classificados como bem-aventurados. Na crônica publicada no Diário Carioca no dia de São João, o autor rendia homenagem ao escritor João Ribeiro. ${ }^{2}$ Seu hagiológio poético-profano reuniu na mesma ceia joãos de distintas épocas e de diversos planos espirituais. Os 40 joãos reivindicados por Humberto de Campos parecem corresponder às muitas faces de João Ribeiro. Poeta, filólogo, pintor, professor, historiador, ensaísta, erudito, tradutor, crítico literário, folclorista... São tantas as curiosidades de João Ribeiro quantas suas preocupações pelo universo intelectual. Múltiplo também é seu nome de batismo: João Batista Ribeiro de Andrada Fernandes. É do próprio autor a explicação para a concisão nominal que o consagraria no universo das letras.

Ainda moço, cortei o Andrada, pois que o Ribeiro de Andrada, por auspicioso que fosse, podia parecer um apelido fraudulento.

Cortei o Fernandes para evitar o João Fernandes que se opõe a Cesar nos provérbios.

E fiquei João Ribeiro e talvez fosse melhor ficar João Batista.

Zanguei-me com o Batista porque um Padre, professor de latim, costumava apodarme:

- "João Batista, abaixe a crista!"

E não só a abaixei, cortei-a de vez.

Sou pois, um mutilado, graças a essas anatomias remotas.

Podia ser pior. ${ }^{3}$

Nascido no interior do Sergipe, a 28 de junho de 1860, João Ribeiro chegou ao Rio de Janeiro em 1881. Como muitos jovens provenientes do norte, fora tentar a vida no centro político e cultural do império. No Estado natal concluiu os estudos secundários e pensou em fazer o curso de medicina na Bahia. Ao verificar sua inaptidão para o oficio, interessou-se pela Escola Politécnica do Rio de Janeiro. A engenharia tampouco lhe agradou. Decidiu-se pelo curso de Ciências Jurídicas e Sociais, concluído na Faculdade do Rio de Janeiro em 1894. Enquanto tentava a vida na capital do País e buscava um oficio condizente com a fortuna intelectual adquirida em sua juventude, dedicava-se ao jornalismo e à literatura. Escreveu em $O$ Globo, de Quintino Bocaiúva (1881), na Época de Zeferino Candido (1887), no Correio do Povo, de Sampaio Ferraz e Alfredo Madureira (1889), e no ano de 1890 assinou a seção Sete Dias em um dos principais jornais do Rio de Janeiro, o Paiz. Paralelamente à atividade de jornalista, buscou emprego público. Em 1885 foi aprovado para o cargo de oficial da Secretaria da Biblioteca Nacional. Nos cinco anos que permaneceu nesta instituição atuou também como Secretário do Instituto Filológico Brasileiro. ${ }^{4}$ Nesse período ganhou reconhecimento e foi convidado pelo empreendedor Francisco Alves para compor um curso de gramática portuguesa em três volumes destinados à educação da infância, ao curso médio e ao curso superior. $^{5}$ 
Antes de fixar-se no Pedro II, passou pelos colégios São Pedro de Alcântara e Alberto Brandão, ambos no Rio de Janeiro. O concurso para o Pedro II foi feito em 1887 para a cadeira de Português. Ficou em segundo lugar, com a tese Morfologia e Colocação dos Pronomes. Malgrado sua classificação, foi nomeado em 14 de novembro de 1890 como lente de história Universal. Foi nesse momento que deu início às pesquisas sobre história. Seu primeiro trabalho na área é tão raro quanto desconhecido. Trata-se do manual chamado História Antiga: Oriente e Grécia, publicado em 1892 pela Livraria Alves e imediatamente esgotado, a ponto de merecer uma segunda edição em 1894.

Apesar do sucesso do livro, João Ribeiro só seria elevado ao panteão dos historiadores a partir do lançamento de História do Brasil: curso superior, publicado em 1900. O livro fazia parte de uma série aos moldes daqueles publicados pela casa Alves, que o tornara conhecido como gramático. A série incluía, além do volume sobre o curso superior, um para o curso médio e outro para o curso primário. Os três volumes foram inicialmente publicados pela Editora Jacinto Ribeiro dos Santos (1900). Neste ano, a casa Francisco Alves preparou uma "edição do Centenário" de História do Brasil: Curso Superior. Em 1901, o mesmo livro ganhou edição ampliada e revisada pelo autor e publicada pela livraria Cruz Coutinho. De acordo com Leão (1954), em 1929 História do Brasil: Curso Superior já estaria em sua 12a edição, sob os cuidados de Francisco Alves. A partir de 1953, saía pela Livraria São José, em 14ª edição revista e complementada por Joaquim Ribeiro.

No portfólio historiográfico de João Ribeiro merecem registro mais duas obras: História Universal, elaborada a partir do programa curricular do Colégio Pedro II e publicada em 1918 (2 $2^{\mathrm{a}}$ ed. 1919) e História da Civilização de 1932. Todos, lançados pela editora Jacinto Ribeiro dos Santos.

A amplidão de sua curiosidade encontra respaldo igualmente nas diversas agremiações de que fez parte. Além da Academia Brasileira de Letras, compôs o quadro de intelectuais dos institutos históricos e geográficos do Rio de Janeiro, de São Paulo e de Sergipe, da Academia de Letras de Sergipe, além de ter sido sócio da Academia das Ciências de Lisboa. Entre 1907 e 1914 atuou como diretor do Almanaque Garnier em substituição a Ramiz Galvão. ${ }^{6}$

No início do século XX colaborou em diversos jornais do Rio de Janeiro, tais como o Correio da Manhã em 1903, o Imparcial em 1912, a Gazeta de Notícias em 1923. A partir de 1927 assumiu a coluna de crítica literária do Jornal do Brasil, em substituição a Osório Duque Estrada, falecido no mesmo ano. Entre 1926 e 1934 colaborou na imprensa paulista. ${ }^{7}$

Em abril de 1934 morria João, com 74 anos de idade. A legenda aurea desse João nascido sob os auspícios de São João Batista, como bem destaca Humberto de Campos, deixava acesa a fogueira da saudade entre os muitos que conviveram ou foram educados por suas lições de gramática e de história. É da chama dessa saudade que nasceriam duas obras sobre a vida do 
escritor. A primeira, publicada por Joaquim Ribeiro, a segunda, por Mucio Leão. Os traços esboçados pelo filho e pelo amigo pairam entre biografia e memória. Uma análise dos recursos narrativos e metodológicos utilizados para a construção dessas obras permite apreciar o processo de criação da memória de João Ribeiro na constelação intelectual brasileira.

Ao observarmos o sucesso do gênero biográfico, dentro e fora das academias, merecem destaque as preocupações elencadas por aqueles que olham com desconfiança, mas ao mesmo tempo almejam uma relação promissora entre história e biografia. Estaria o historiador-biógrafo assumindo o papel do voyeur, ávido por espiar a vida dos outros? Estaria retomando uma antiga modalidade de pesquisa, pautada na história dos indivíduos desencarnados ou heroicizados? Estaria atento antes às seduções do mercado editorial do que a uma pesquisa que tivesse como compromisso a profissão abraçada e que o obrigasse a um contrato ético e político com seu métier? Estaria, por fim, projetando no outro suas próprias idiossincrasias? O cuidado para não ceder a tais encantos sedutores moveu a interpretação das fontes selecionadas para a construção deste trabalho. Em face disso, inicialmente serão analisados os dois primeiros empreendimentos biográficos sobre João Ribeiro para, em seguida, perscrutar seu posicionamento político bem como as dificuldades enfrentadas por ele para se fixar no Rio de Janeiro.

As biografias de João Ribeiro foram produzidas no período que Marcia de Almeida Gonçalves (2011) nomeou como "tempos de epidemia biográfica". Como se verá na análise proposta adiante, são trabalhos produzidos entre os anos 30 e 40, logo, cronologicamente próximos das biografias lançadas pela coleção "Documentos Brasileiros" e analisadas por Gonçalves. ${ }^{8}$ Apesar de produzidas na mesma época em que Octavio Tarquinio de Souza publicava suas biografias históricas, os trabalhos de Joaquim Ribeiro e Mucio Leão não compartilhavam os mesmos lugares de produção. Seus livros nasceram das relações afetivas com o biografado, provinham do seio familiar (Joaquim) e do ambiente compartilhado na Academia Brasileira de Letras (Mucio). Se isso não explica, ao menos ajuda a compreender os pontos que os biógrafos resolveram iluminar da trajetória profissional e pessoal de João Ribeiro.

Como gênero em florescimento nas pesquisas acadêmicas, a escrita biográfica tem sido não apenas bem produzida por historiadores renomados, também seus métodos e desenvolvimento têm sido explorados de modo a contribuir para o avanço do conhecimento e da pesquisa em história. Como bem salienta Sabina Loriga (2011), o crescente interesse dos historiadores pela escrita biográfica está relacionado ao cerne das questões relativas ao papel dos sujeitos na história. Ao confrontar os aportes narrativos e metodológicos utilizados na produção de biografia entre jornalistas e historiadores, Benito Bisso Schmidt (1997) chega a conclusões semelhantes. Em suas palavras, "a recuperação dos sujeitos individuais na história pode ser vista como uma reação aos 
enfoques excessivamente estruturalistas, descarnados de 'humanidade', que caracterizaram boa parte da produção historiográfica contemporânea" (SCHIMDT, 1997, p. 3).

Todavia, convém perguntar: afinal, o que é fazer uma biografia? A historiadora Lucia Maria Bastos Pereira das Neves, empenhada desde longa data na empreitada de escrever uma biografia de D. João VI, afirma que é preciso evitar algumas armadilhas. O primeiro conselho, toma-o emprestado de Philippe Levillain, quando sugere evitar o desejo de "esgotar o absoluto do eu do personagem" (NEVES, 2011, p. 309). O segundo é cuidar para não apagar o biografado nas neblinas do contexto histórico. Por fim, escapar do risco de estabelecer uma cronologia absoluta. Em síntese, a autora ressalta a necessidade de "fazer uma descrição minuciosa da vida do biografado, constituída por pequenos fatos, até aparentemente insignificantes, mas que, uma vez densamente entrelaçados, emprestam ao todo um significado mais amplo" (NEVES, 2011, p. 310). Este artigo busca seguir as trilhas anunciadas no diário de bordo construído por Lucia Pereira das Neves.

\section{Em nome do pai}

Tal como o pai, Joaquim Ribeiro dedicou-se ao ofício das letras e da história. Estudou no Pedro II e formou-se em Direito. Após a morte de João, dedicou-se a manter viva a memória do mestre. Incumbiu-se de buscar apoio financeiro para reeditar os livros esgotados e publicar trabalhos inéditos. ${ }^{9}$

No que tange à divulgação e à preservação da memória de João Ribeiro, é possível destacar a coletânea que publicou dois anos após a morte do pai, sob o título O elemento negro. São 237 páginas de textos dispersos na fortuna crítica de João Ribeiro, que versam sobre temas, tais como: linguística, história e folclore das populações negras no Brasil. Além disso, Joaquim Ribeiro cuidou pessoalmente das reedições de História do Brasil: curso superior. Tais cuidados se fazem notar a partir dos acréscimos, notas e comentários efetuados por Joaquim a partir da $14^{\mathrm{a}}$ edição do manual, publicado pela Livraria São José em 1953. De sua peregrinação afetivo-intelectual, o livro que mais nos interessa para os limites deste trabalho foi publicado no ano da morte do escritor (1934) pela editora Record. ${ }^{10} \mathrm{O}$ título 9 mil dias com João Ribeiro faz referência ao tempo de convívio que o filho teve com o mestre, desde o nascimento, em 1907. Na primeira página, intitulada "Em vez de prefácio", o autor anuncia: "Este livro não é romance. Nem biografia. Não é retrato. Nem caricatura de João Ribeiro. É apenas um pouco de seu ceticismo voltairiano, de sua maliciosa jovialidade, de sua vida íntima e anedótica, enfim de suas virtudes defeituosas e de seus defeitos virtuosos..." (RIBEIRO, 1934, p. 7). Nesse introito, o autor tenta livrar-se da parelha biográfica, por ele identificada como registro de datas e nomes, com predomínio para a função encomiástica. Apesar 
disso, deixa escapar que o livro tangencia o gênero, ao confessar: "9 mil dias com João Ribeiro há de ser um trote para os que esperavam uma biografia com datas e genealogias ou algum ensaio crítico sobre a obra de meu querido mestre e progenitor” (RIBEIRO, 1934, p. 154).

As fontes a que recorre para construir o livro foram recolhidas de frases dispersas capturadas na obra de João Ribeiro, em sua própria memória e, mesmo, do folclore criado a respeito do escritor. Segundo o filho-biógrafo: "nesta recolta de anedotas e episódios íntimos está, talvez, o maior elogio à sua personalidade" (RIBEIRO, 1934, p. 8). A tais matérias, acrescenta Joaquim: "ajuntei algumas referências de amigos e discípulos de João Ribeiro que fixaram uma ou outra anedota curiosa" (RIBEIRO, 1934, p. 9). Com esse procedimento, o autor exclui todas as críticas e arengas dirigidas a João Ribeiro para ressaltar tão somente os elogios. A narrativa aparece em primeira pessoa e flui como obra de memória, sem preocupação com o encadeamento cronológico, embora com certa precisão no registro das fontes impressas, tais como data de tal ou qual crônica ou texto publicado por algum amigo ou crítico sobre João Ribeiro.

Em uma lembrança que vai ao encontro das ideias de Maurice Halbwachs ao argumentar que "cada memória individual é um ponto de vista sobre a memória coletiva" (HALBWACHS, 2006, p. 69), Joaquim Ribeiro sai em busca da primeira memória que tem do pai: "Lembro-me, como saudade mais remota de minha vida, nem de meu pai, nem de minha mãe, mas do que há de mais longínquo e de mais distante na memória: a cara encarquilhada de uma preta velha, a Preciosa, que me pajeava e fazia ninar" (RIBEIRO, 1934, p. 14). E continua: "Depois vem a lembrança da casa antiga, acachapada, povoada de gente, e da chácara, enorme, povoada de árvores” (RIBEIRO, 1934, p. 15).

O primeiro capítulo do livro é inteiro baseado em suas memórias infantis. A evocação é tão pessoal quanto poética "[nas lembranças] tudo se enevoa num turbilhão de reminiscências fugidias, difíceis de serem discriminadas isoladamente. Os acontecimentos são como que baixos relevos fragmentados, esparsos, em ruínas" (RIBEIRO, 1934, p. 14). Aos poucos, o narrador ajeita o foco e nos apresenta o menino Joaquim espiando o mestre, ora na sombria sala de leitura "eu chegava, muita vez, na porta, olhava-o e sentia um temor inexplicável. Não gostava da biblioteca" (RIBEIRO, 1934, p. 16), ora no quintal ensolarado em que João exercitava uma de suas paixões, a pintura: "Todos nós, eu, os meus irmãos pequenos e às vezes algum moleque, filho da cozinheira, nos apinhávamos em redor dele, bisbilhotando, discutindo, num espanto ingênuo, enquanto a tela se transformava em cores" (RIBEIRO, 1934, p. 16). Recorda ainda a viagem para a Europa e a surpresa ao descobrir no vapor que os conduzia a capacidade do pai de se comunicar em outras línguas. As lembranças avançam cronologicamente até o momento em que o biógrafo registra sua entrada na Escola Pública e a reverência das professoras que diziam ter aprendido gramática com seu pai “desde então descobri um mundo de coisas ignoradas na obra e na personalidade de meu 
pai: o poeta e o prosador, o filólogo e o didata, o historiador e o filósofo, o folclorista, o esteta, o crítico, o romancista, o humorista, o polígrafo, o humanista enfim.” (RIBEIRO, 1934, p. 18)

Nos catorze capítulos do pequeno livro é evidente o esforço do autor em fabricar um personagem com perfil que se aproximasse da imagem que tinha do iluminista francês Voltaire, em suma, um sujeito versado em diversas disciplinas, focado no trabalho, mas altamente generoso, brincalhão e avesso aos rigores e formalidades, o que o fazia notório entre os colegas. Embora o livro seja carregado de lembranças pessoais, a ênfase é dada antes ao intelectual que ao pai. Tal fato se evidencia nas constantes referências que faz ao "adorável mestre" e ao "progenitor". 11

Outro traço marcante no livro de Joaquim Ribeiro diz respeito à tentativa de expurgar os traços julgados negativos atribuídos a João Ribeiro em sua trajetória intelectual. Nesse ponto o autor assume o papel do biógrafo-advogado. Na contramão de um intelectual ateu, mostra quanto João Ribeiro se dedicava à leitura da Bíblia e de livros sacros e acaba forçando situações que o colocam como simpático ao cristianismo, ao ressaltar a amizade que manteve com o arcebispo de Mariana, D. Silvério Gomes Pimenta, ou a "suave obsessão" por ler biografias de Jesus: "Mania cristã já se vê" (RIBEIRO, 1934, p.31).

Em 9 mil dias com João Ribeiro é perceptível o esforço do autor para reabilitar a imagem do mestre de todas as críticas que sofrera em sua trajetória profissional tanto quanto para lançar um sopro de leve candura humorística a seu perfil. O esforço denuncia os respingos que poderiam manchar a imagem do imortal na posteridade. Mais do que desmistificar a construção que Joaquim fizera do João, cabe aqui ressaltar quanto esse empreendimento nos revela sobre o que se fazia pertinente combater, à época.

Em correspondência de Capistrano de Abreu, escrita em 1920 a um amigo, encontramos pistas da fama de João Ribeiro ser mal humorado e afeito a querelas intelectuais. ${ }^{12}$ Em que pesem as desavenças pessoais e intelectuais existentes entre eles, ${ }^{13}$ as críticas possuem fundamento e podem ser mapeadas em outros autores. O próprio empenho de Joaquim Ribeiro em apagar esses traços faz eco à verdade dessas impressões, bem como o quanto elas maculavam a imagem do mestre. Como antídoto para o joão ranzinza e brigão, por exemplo, Joaquim apresenta o joão voltado para as artes, complacente com os novos escritores e crítico da ortodoxia gramatical. Contra o joão metódico e totalmente mergulhado no universo intelectual, pincela um sujeito distraído e generoso, que esquecia os pontos sorteados para sabatinar seus alunos, no colégio Pedro II. Contra o joão denunciado pelos compatriotas por menoscabar suas origens nordestinas, arremata o quanto os fatos, folclores e memórias do Sergipe povoaram sua fortuna intelectual.

O capítulo final do livro é dedicado à infância de João Ribeiro. Está centrada na memória da avó paterna. Descreve o gosto pelas guloseimas, as amizades, a relação com as garotas, a paixão pela música, os discursos proferidos na escola e a genealogia da família, enfim, o arremate tem o 
toque de leveza buscado desde o início da obra, e, nesse sentido, nada mais convincente que recorrer às memórias da infância do escritor a partir da autoridade do discurso de sua mãe.

Ao fim, o livro compartilha com a escrita biográfica mesmos vícios e vantagens. No plano ficcional, a tentativa de fixar determinada imagem do personagem: o Voltaire à brasileira; no plano pessoal, a busca apaixonada por remover todas as críticas feitas ao biografado, ao menos aquelas que naquele período se faziam pertinentes expurgar; no plano historiográfico, o texto compartilha o exercício de variar as fontes e de, sempre que possível, explicitá-las; no plano da memória, recordações que deixam em segundo plano o pai, para fazer brilhar o mestre. Não parece fortuito o empreendimento que moveu Joaquim a ressaltar a jovialidade do pai, exatamente no momento final de sua vida. Ele atacou os pontos que atingiam diretamente a consagração da memória do paimestre-progenitor.

\section{João Ribeiro modernista, humanista e mestre}

As primeiras iniciativas para a publicação do acervo literário de João Ribeiro ocorreram nos anos 1940, possivelmente por entusiasmo pela proximidade do aniversário de uma década da morte do escritor. Entre 1941 e 1945, Mucio Leão proferiu discursos e publicou em jornais e revistas textos sobre João Ribeiro. ${ }^{14}$ Ângela de Castro Gomes (1996) analisa os textos de Mucio Leão, publicados em Autores e Livros, nesse período. Ao que parece, o esforço rendeu bons frutos, uma vez que se viu sinalizado o compromisso do governo de financiar o projeto. Seu depoimento permite acompanhar os meandros políticos da empreitada:

Em certo momento, tivemos a ilusão de que as Obras Completas desse grande escritor, desse clássico brasileiro, poderiam vir, enfim, à luz: foi quando, apresentado pelo Deputado Agamenon de Magalhães à Câmara, o projeto que as mandava editar, abrindo para isso o crédito de um milhão e quinhentos mil cruzeiros, se viu (contra o voto do então deputado Gilberto Freyre) transformado em lei pelo Presidente Eurico Dutra - Lei n. 1024. Mas os fados continuaram conspirar contra João Ribeiro: sancionada pelo Presidente de República, a Lei n. 1024 só poderia de fato entrar em vigor quando o crédito necessário às publicações a que ele se referia fosse entregue ao Instituto do Livro, órgão por conta do qual as obras seriam organizadas e impressas. Na hora da distribuição desse crédito, um funcionário burocrático opôs-se à decisão presidencial, e, meditando que o Brasil não pode gastar dinheiro com essas coisas de livros e de cultura matou a Lei, sepultando-a no fundo de uma escusa gaveta (LEÃO, 1952, p. 10).

Engavetada, do mesmo modo permaneceu por quase uma década a vasta pesquisa realizada. A oportunidade surgiu quando, na década de 1950, a Academia Brasileira de Letras aceitou publicar os trabalhos de João Ribeiro. No entanto, não seria possível dar conta de todo o acervo literário reunido por Mucio Leão, teria que sair aos poucos, de acordo com as conveniências do momento e 
dos recursos financeiros. Mucio Leão privilegiou a publicação dos textos de crítica, em um total de 16 volumes, dos quais apenas 7 foram publicados pela ABL entre 1952-1961. São eles: v.1. Clássicos e românticos brasileiros - v.2. Poetas parnasianismo e simbolismo - v.3. Autores de ficção - v.4. Críticos e ensaístas - v.5. Filólogos - v.6. Historiadores - v.9. Os modernos. A ordem de publicação não seguiu o critério da numeração, pensada na organização original, programada para sair de uma só vez. Conforme declara o organizador: "alguma vez, para atender a conveniências do momento, alteraremos a ordem que adotamos." (LEÃO, 1952, p. 14). Os primeiros volumes publicados foram os de números 1 e 9, este, dedicado à crítica de Ribeiro sobre escritores modernistas. Tal critério explica também o motivo do vazio verificado entre os volumes 6 e 9. Os de números 7 e 8 nunca foram apresentados ao público. Ainda como registro de um empreendimento naufragado e, ao que parece, perdido, merece destaque outro fragmento do depoimento de Leão.

Acrescente-se que, na seriação da Crítica, tal como a organizamos, depois do volume reservado aos Modernos, virão cinco volumes excelentes: são aqueles em que João Ribeiro fez a crítica de autores de assuntos estrangeiros. Um deles (que é dos mais deliciosos de toda a série) trata dos viajantes e naturalistas estrangeiros, que viram ou descreveram o nosso país; outro abrange os temas relativos a todo o continente americano; um terceiro, os relativos ao continente europeu (excluídos os temas portugueses e os alemães); um quarto, os relativos a Portugal; o último, os relativos à Alemanha. Estes dois últimos volumes - assuntos portugueses e alemães - nos parecem ter uma importância primordial, no majestoso conjunto da obra do grande crítico (LEÃO, 1952, p. 14).

Constata-se que não somente o trabalho integral do pesquisador foi frustrado, como também a liberdade em escolher quais obras publicar, uma vez que os volumes que mais agradavam ao organizador permaneceram no escuro da gaveta. ${ }^{15}$

Mas os ventos soprariam favoráveis por ocasião das comemorações dos 100 anos do nascimento de João Ribeiro. A tradição intelectual, ávida por fenômenos comemorativos, deu ensejo a novos empreendimentos editoriais das obras do mestre. Parece ter sido nessa onda que História do Brasil: curso superior ganhou versão ampliada e comentada por Joaquim Ribeiro. Além disso, destaca-se uma brochura que serviu como suplemento da Revista do Livro, v. 4, ano $V$ de setembro de 1960, dedicada a publicar um levantamento bibliográfico sobre o intelectual. Na série "Nossos Clássicos", a editora Agir, dirigida por Alceu Amoroso Lima, Roberto Alvim Corrêa e Jorge de Sena, convidou Mucio Leão para organizar o volume intitulado João Ribeiro: trechos escolhidos, com 91 páginas. No mesmo ano, saiu pela Livraria São José nova edição de uma obra ficcional chamada Cartas Devolvidas, cujo prefácio coube a Joaquim Ribeiro. O livro foi apresentado como um dos "mais estimados" pelo autor, pois ali se encontrariam "mensagens de erudição e de ideias que definem, em toda plenitude, o espírito de João Ribeiro. Nelas, o estilo 
alcança a cristalização apropriada para traduzir a limpidez do pensamento e a riqueza da erudição" (RIBEIRO, 1960, p. v).

Por essa época, História do Brasil: curso superior chegou ao público em versão definitiva pela Francisco Alves. À nova edição foram acrescentadas notas explicativas, índice de antropônimos, de topônimos e intitulativos, o prefácio da segunda edição escrita por Tristão de Alencar Araripe Junior, a versão original em alemão, seguida da tradução, do comentário sobre o livro feito pelo padre jesuíta do Rio Grande do Sul Carlos Teschauer e um prefácio original escrito por Joaquim Ribeiro, intitulado “A posição doutrinária de João Ribeiro na historiografia nacional”.

Por fim, o empreendimento da Livraria São José que mais interessa aos planos desse texto. Trata-se de algo próximo a uma biografia intelectual de João Ribeiro, elaborada por Mucio Leão e publicada em 1962.

Mucio Leão (1898-1969) foi o acadêmico que ocupou a vaga de Humberto de Campos na Academia Brasileira de Letras em 1935. ${ }^{16}$ De João Ribeiro, herdou a coluna de crítica no Jornal do Brasil (RJ). O escritor levou a sério a tarefa de discípulo. Tal como um colecionador de antiquário, recolheu e guardou tudo que encontrou da safra intelectual do escritor, do momento em que se fixou na capital do Império até sua morte.

Talvez o mais ambicioso dos seus trabalhos tenha sido a organização das obras completas de João Ribeiro. Pelas suas contas e pesquisas, compreendiam 59 volumes. Destes, 24 haviam chegado ao público, os demais estavam dispersos em páginas de jornais.

No que tange à biografia de João Ribeiro, Leão construiu aproximadamente 15 perfis do amigo e mestre distribuídos em 291 páginas. Entre eles, os de pintor, viajante, memorialista, acadêmico, crítico, erudito e ensaísta. Tal como os 9 mil dias, de Joaquim Ribeiro, o autor opta por montar uma série de quadros, espécie de traços biográficos do intelectual. Ao que parece, os capítulos são síntese do plano estabelecido por Mucio na organização das obras jornalísticas de João Ribeiro, já divulgadas na década de 1940. Há que observar, inclusive, que os 15 capítulos coincidem com os 15 volumes voltados à crítica de obras literárias, apresentados no esboço da obra completa.

Nessa biografia, as fontes utilizadas revelam a intimidade do autor com os textos jornalísticos, correspondências, projetos e depoimentos de e sobre João Ribeiro. São relatados episódios peculiares, recolhidos tanto de suas crônicas quanto do testemunho dos convivas de João. Ainda que compartilhe de uma narrativa que revela traços muito pessoais do escritor, não se encontra na obra de Mucio Leão o zelo verificado em Joaquim de forçar um perfil "voltairiano" para o mestre. Seu João é mais multifacetado e, em alguns momentos, contraditório. Sequer aparece fazendo tantos gracejos quanto em 9 mil dias. Investe-se na imagem do escritor versado em humanidades. Sobre o poeta, filólogo, romancista e folclorista, sobressai o João Ribeiro crítico e 
ensaísta. Nesse roteiro, aposta no João "precursor do modernismo", fato coerente com o clima de comemoração dos 30 anos da Semana de Arte Moderna promovida pela ABL.

Mucio Leão destaca correspondências e impressões do intelectual feitas com grandes personalidades da época, tais como Joaquim Nabuco e Graça Aranha, posicionamentos sobre questões sociais delicadas, tais como feminismo e o envolvimento da Alemanha na Primeira Guerra Mundial, a reminiscência do escritor à época da infância em Sergipe. Flagra alguns registros em que Ribeiro rende homenagens aos seus mestres, faz referências sutis às questiúnculas políticas da ABL, suas impressões de leituras e troca de correspondências com escritores estrangeiros.

Em síntese, se em 9 mil dias é possível espiar com maiores nuances a ação do Joaquim no processo de construção do joão, em Mucio predomina uma imagem esboçada em pequenos quadros, sem a preocupação em fazer uma biografia bem acabada. Esta, embora fragmentada, tem como vantagem permitir ao pesquisador reunir, redistribuir e colar os pedaços no exercício de montar novos retratos de João Ribeiro. No entanto, é patente nos dois autores o silêncio a qualquer menção à filiação político-partidária de João Ribeiro, assim como às dificuldades financeiras enfrentadas em seu ingresso na Capital do Brasil. Quando muito, os autores tratam de forma breve de algumas polêmicas intelectuais, como a que João travou com Carlos de Laet sobre colocação pronominal, ou uma querela com José Veríssimo, ao que parece, motivada por comentário feito em livro sobre a história da literatura brasileira escrito em parceria com o amigo e conterrâneo Silvio Romero. Na tentativa de contribuir para a construção do perfil do escritor, as páginas abaixo serão dedicadas a algumas considerações sobre seu posicionamento político e fixação no Rio de Janeiro. Para tanto, no que diz respeito às notas biográficas, a fonte por excelência será o pequeno texto de apresentação ao ensaio bibliográfico que Mucio Leão elaborou sobre João Ribeiro em 1954. Sempre que possível, será interrogada antes a forma que o conteúdo expresso no texto. Sobre este, não há o que acrescentar à impecável pesquisa do discípulo e amigo.

\section{Posicionamento político e nostalgia da Europa}

Por volta de 1907, João do Rio conseguiu de Ribeiro um depoimento para compor o que denominou "Inquérito Literário". Questionado sobre o estado da prosa e da poesia contemporânea, João Ribeiro deixa escapar certa desilusão com o universo intelectual do Brasil. Afirma depositar esperanças em novos prosadores e, sem citar nomes, confessa não ver futuro na poesia do momento: “prefiro ler um anúncio de leilão a um soneto" (RIO, 1994, p. 24). Ao longo do depoimento, é bastante cauteloso, mas em determinado momento desabafa: "Já transpus os limites da discrição, e numa sociedade primitiva e guerreira como esta, democracia pela força das coisas, mas sem nenhuma educação liberal, e em que a regra é eliminar os discordantes, com o que disse já estou 
muito mal parado" (RIO, 1994, p. 25). Para os iniciados nos mistérios de Clio, difícil não reconhecer nessa observação uma crítica ao momento político do Brasil, em especial à política oligárquica que tomava conta do País e decepcionou diversos intelectuais que apoiaram o novo regime (cf. OLIVEIRA, 1990).

Como dito acima, o sergipano de Laranjeiras chegou ao Rio de Janeiro em 1881. A vida na capital federal impunha posicionamentos. Ainda que não tenha participado das reuniões promovidas pelas elites políticas da época, posto não dispor de grande capital financeiro, tampouco deixou de conviver com intelectuais notórios. $\mathrm{Na}$ atividade de jornalista certamente manteve contato com homens para quem a convicção política era bandeira desfraldada. Atuou no jornal do famoso republicano histórico Quintino Bocaiúva. Por meio da imprensa, estreitou laços de amizade com o jornalista e político Alcindo Guanabara e com Edmundo Bittencourt (LEÃO, 1954). Na ABL conviveu com políticos atuantes, sem contar a amizade e parceria que estabeleceu com um dos mais polêmicos e politizados intelectuais do seu tempo, Silvio Romero (cf. VENTURA, 1991).

Acrescente-se a essa lista o fato de que, nos 20 últimos anos do século XIX, o País foi sacudido por mudanças abruptas na política: a Proclamação da República, a disputa entre radicais e monarquistas, a Revolta da Armada e a guerra de Canudos agitariam o Rio de Janeiro e todo o Brasil. Isso, para ficar apenas no final do XIX, uma vez que no século XX, em especial o período da década de 30, a situação não seria menos agitada.

Sobre o assunto, Joaquim Ribeiro nada diz, tanto quanto Mucio Leão. Coube a pesquisadores da década de 1990 atentar para o fato. Patricia Hansen faz análise detalhada do envolvimento de Ribeiro com a questão republicana ao destacar que, no inicio, a atitude do escritor foi de expectativas quanto ao novo regime. Para tanto, inclui como evidências as crônicas que ele publicou no calor da hora, assim como correspondências trocadas com amigos. De acordo com Hansen, “Após a proclamação, João Ribeiro apoiou os governos militares, manifestando-se sempre e de maneira apaixonada a favor de Floriano Peixoto" (HANSEN, 2000, p. 27). Nesse sentido, reproduz fragmento da carta de João Ribeiro, enviada a um amigo dias após a Proclamação, em que declarava: "Sou republicano antigo, bem o sabes; mas hoje há tantos republicanos que tenho quase vergonha de declarar-me tal” (apud HANSEN, 2000, p. 28). Em breve, mas bem amparada, análise, Hansen acompanha a mudança do seu posicionamento político. A autora é certeira no diagnóstico ao alistar João Ribeiro na fileira dos decepcionados com os rumos republicanos:

[...] seria ao longo do período correspondente ao governo de Prudente de Morais, de 1894 a 1898, que nosso autor iria tornar-se cada vez mais cético e pessimista. E essa transformação iria, se acompanharmos a sequência de suas cartas no período, ocorrer paralelamente às repetidas frustrações de suas expectativas em relação à obtenção de cargos públicos (HANSEN, 2000, p. 28). 
Data desse período sua primeira viagem à Europa. Partiu em abril de 1895. Visitou diversos países, mas enamorou-se pela Alemanha. Berlim o encantou de tal forma que escreveu ao amigo Lucio de Mendonça “quero voltar alemão e disciplinado". ${ }^{17}$ Nesse período, conseguiu levar a família. Ficou tão embevecido com tudo que viu que, em carta remetida meses depois a José Lino para lamentar a morte do filho de seu compadre e amigo, mais ressaltou o encanto com a Europa que a tristeza da perda. Na correspondência destacou o quanto se encantou por Paris e a possibilidade de representar o Brasil na Inglaterra durante evento ligado à instrução pública. Terminou a missiva, que deveria ser de pêsames, de forma empolgada: “A Europa é magnífica". 18

Ao findar sua missão oficial na Europa, de tudo fez para adiar seu retorno. Hansen destaca as cartas enviadas a todos quantos pôde recorrer com o fito de conseguir algum cargo oficial que o fixasse no Velho Mundo. Não atingindo êxito e tendo verificado que alguns, antes pelas relações pessoais que pelos dotes intelectuais, atingiam tais misteres com todas as despesas pagas, desencantou-se com a política e, ao que parece, culpou a República por essas mazelas. Para além dessa frustração pessoal, há que não desprezar a possibilidade de que a distância e a experiência do outro lado do oceano o fariam enxergar os rumos do poder no Brasil sob diferente perspectiva.

Em 1898, já estava de volta ao Brasil e ingresso na Academia Brasileira de Letras. Os anos seguintes seriam de total desolação. Desejava voltar à Europa. Em 1900 mantém correspondência frequente com o escritor e amigo Graça Aranha. Na primeira carta, escrita em janeiro de 1900, confessa que desde que retornou ao Brasil não era mais o mesmo "depois que vim de lá, bem o sabes, nunca me pude curar da nostalgia da Europa". ${ }^{19}$ Na sequência, reclama da saúde, da cidade, da solidão. Já se apresenta totalmente desacreditado da política. Nesse período está prestes a completar 40 anos de idade. Em sua confissão pessoal não esconde seu desencanto com o País e, curiosamente, declara-se pelo imperador:

\footnotetext{
Sabes que não gosto do atual Brasil. O único laço que me prende a ele é o Imperador, porque não posso separar a minha pátria do império. Cessando de crer n'um deles, cessarei de crer no outro. E quando isso eu verificar, emigrarei com meus deuses, não sei para onde [...]. É o que devem fazer os vencidos se escapam do massacre triunfante. Por isso mesmo resolvi nada escrever contra a República e depus a pena, até que os próprios republicanos iniciem a reação. Demais não tenho prestígio para falar e não quero falar em vão. ${ }^{20}$
}

Sua virada monarquista não ficou restrita ao âmbito confessional e íntimo que se pode observar na troca de cartas entre amigos. Ao que parece, tornou-se pública e declarada. Capistrano de Abreu a comenta com bastante ironia ao escrever a um amigo: "Não poderia informar como foi a primeira vez a Europa, como voltou monarquista da Alemanha, como resolveu consagrar-se a pintura e se ainda continua a cultivá-la". ${ }^{21}$ 
Na sequência das correspondências enviadas a Graça Aranha, em 1900, é possível observar amargura e desespero. Na carta de 6 de junho de 1900, de caligrafia bastante trêmula, confessa: "rabisquei as linhas anteriores na sala de jantar e em conselho da família". ${ }^{22}$ Pede ao amigo que interceda junto a Joaquim Nabuco para que seja nomeado para algum cargo na Europa. Em sua solicitação argumenta que precisa de ofício remunerado:

Não tenho dinheiro, se me derem ajuda de custo, irei com a família; esta iria 3 ou 4 meses depois se não me derem com que pagar as passagens. Não posso separar-me por muito tempo das mulheres e dos filhos (que são agora 4, porque há duas semanas nasceu-me um João). ${ }^{23}$

O remetente tem consciência do tamanho do favor que solicita e se confessa envergonhado pelo pedido, mas declara que, no estado em que se encontrava e com as relações pessoais que possuía no Rio de Janeiro, só lhe restava recorrer ao amigo. Conclui, afirmando: "Eis ai uma carta que não merece a honra da tua gaveta cheia das boas correspondências. Peço-te que advogues junto ao Nabuco [...] o meu desejo. Não creio que ele ache extemporâneo quando agora as finanças sorriem e sou eu que o peço". ${ }^{24}$

Outra correspondência remetida ao autor de Canaã no dia seguinte, embora mais ponderada, sugere, pelo curto tempo da redação, quanto estava agitado pela ideia de voltar à Europa: "Escrevi ontem e nervosamente, para de um golpe formular-te o pedido que te fiz. Faço-o de novo agora, para confirma-lo com calma e reflexão". ${ }^{25}$ Confidencia ao amigo: "Estou farto do Rio de Janeiro: letras, artes (que não há) e política, sobre o que há mais de um ano deixei de pensar”. ${ }^{26}$

Passados cinco meses, nenhuma resposta. Nova carta é enviada. A medida do desespero beira o inconveniente. Ribeiro o pressente, mas não se contém:

Foi-me preciso um grande fôlego de coragem para começar a escrever essas linhas... De certo! Escrevi-te ao abrir-se de junho, com um desejo e uma importunação, e até hoje (que lonjura!) não te arranquei sequer uma palavra. Não sei que coisas irresponsáveis te escrevi eu... Mas não levo a mal o teu silêncio que evidentemente tem qualquer coisa boa e algum sentido útil. Porque és bom e amigo. $^{27}$

Apesar da desilusão e nostalgia, o regresso ao Rio de Janeiro marcou um período produtivo na vida do intelectual. Com base nas aulas de pintura que tomou em sua estadia na Alemanha, produziu telas suficientes para montar uma exposição dos seus quadros, no ano de 1900. Nesse mesmo ano, publicou a série de livros didáticos que o consagraria no métier do historiador. Diferentemente dos quadros que foram bombardeados pela crítica, os manuais de história do Brasil foram imediatamente saudados com entusiasmo, em especial o exemplar destinado ao curso superior. 
Em 11 de maio de 1901 chegava à Europa pela segunda vez. De acordo com Mucio Leão, viajou como "adido extraordinário à Embaixada Brasileira no litígio anglo-brasileiro da Guiana Inglesa, Embaixada de que era chefe o seu grande amigo Joaquim Nabuco" (LEÃO, 1954, p. 24). Antes de findar o ano, já estava de volta. Em 1903, verificam-se novas correspondências, desta vez remetidas por Nabuco com pedido de desculpas por não vir a seu socorro. Com a polidez de um diplomata experiente, aconselha João Ribeiro a permanecer no Brasil. Exalta o talento do escritor e o reconhecimento que possui em seu país. Ademais, destaca que, para o bem da família, o melhor seria criar os filhos junto aos amigos e parentes, em ambiente em que pudessem fincar raízes e ser bem acolhidos. Em determinado momento da missiva, aconselha: "se quer sair do Brasil, faça-o sem a responsabilidade dos que o consideram uma das superioridades e o orgulho da nossa terra". ${ }^{28}$ Ao que parece, a partir desse momento João Ribeiro desiste de vez de nomeação política. Apesar disso, não abandona o sonho de retornar à Europa.

Conforme as notas biográficas de Mucio Leão (1954), em 1913, vende a casa que possuía em Santa Teresa, no Rio de Janeiro, se desfaz de seu maior patrimônio - sua biblioteca - e segue para a Europa. Decide se instalar em Genebra, na Suíça. Ali pretende educar os filhos e manter vida modesta. Deixa no Brasil apenas a filha Betty, já casada com Rodolfo Sinigalia Xavier. Não podia prever os acontecimentos que estavam por vir e que derrubariam de vez os seus sonhos: a eclosão da Primeira Guerra Mundial. Em 1914 retorna ao Brasil para não mais voltar à Europa.

\section{João Ribeiro, a fixação no Rio de Janeiro e suas viagens à Europa}

Como visto acima, o autor teve que implorar ajuda de custo para deixar o País. Se quando se tornou consagrado como professor do Colégio Pedro II, autor de livros de sucesso e membro da $\mathrm{ABL}$, não possuía capital financeiro suficiente para levar adiante seu plano de fixar residência na Europa, o momento de sua fixação no Rio foi mais dramático.

Coerentes com os esforços de construir uma imagem que ressaltasse o perfil intelectual de João Ribeiro, Mucio Leão e Joaquim Ribeiro sequer mencionam as dificuldades enfrentadas pelo jovem João Batista, proveniente de Laranjeiras, Sergipe, ao chegar ao Rio de Janeiro. Se havia a possibilidade de o filho ignorar tal mister, o mesmo não se aplica a Mucio Leão. Foi este que cuidou, coletou e organizou as obras completas de João Ribeiro, havendo entre os volumes preparados ao menos um integralmente dedicado à correspondência. Mucio Leão foi também membro da ABL, instituição que atualmente abriga em seu arquivo umas poucas e seletas missivas de João Ribeiro, entre as quais se encontram as remetidas para Paraíba do Sul, cujo destinatário é o amigo José Lino. Fixar-se nessa fase é iluminar um dos momentos de maior dificuldade na vida de João Ribeiro e de tantos outros que, como ele, foram tentar a vida na capital do Império. Sua 
trajetória parece ilustrativa das experiências compartilhadas por uma geração de intelectuais, tais como Silvio Romero, Gustavo Barroso e Capistrano de Abreu que, vindos do norte, traziam como maior fortuna a inteligência, pequena experiência como jornalista e poeta na cidade natal e o sonho de fazer-se notado pelo conhecimento adquirido.

O menino João Batista Ribeiro de Andrada Fernandes, se não provinha de família afortunada, tampouco era despido de certos bens. Relata-nos Mucio Leão que seu pai, Manuel Joaquim Fernandes, era filho de portugueses e exercia a profissão de guarda-livros de casas comerciais em Laranjeiras. João foi o segundo filho que o guarda-livros teve com dona Guilhermina Rosa Ribeiro Fernandes. Ficou órfão de pai muito cedo e foi criado pelo avô Joaquim José Ribeiro “que era um espírito liberal, admirador entusiasta de Herculano e de Saldanha Marinho" (LEÃO, 1954, p. 8). Talvez a melhor definição de sua personalidade venha do próprio João Ribeiro. No depoimento que deu a João do Rio, declarou:

As minhas origens espirituais, pois, são, como a social, plebeias, rústicas e pobres, mas nunca pediram de saco e brado pelas ruas. As minhas expansões nunca fizeram explosão que pusesse em perigo o teto paterno: acomodaram-se no estreito ambiente doméstico e suportaram a pressão do silêncio externo (RIO, 1994, p.22).

Sua educação foi austera. Estudou em colégios tradicionais - as primeiras letras, em Laranjeiras, o secundário, na capital do Sergipe. Mucio Leão, fiel à proposta biográfica que antecipa o futuro profissional do biografado no momento mesmo de sua meninice, afirma que o Ateneu onde João Ribeiro estudou em Aracajú possuía "um sistema peculiar de classificação dos estudantes. O primeiro aluno da classe é o Imperador; o segundo, o Consul; o terceiro, o Pretor. João Ribeiro é sempre o 'Imperador'. Apenas uma vez perdeu esse lugar, mas logo voltou a conquistá-lo" (LEAO, 1954, p. 13). Na formação das primeiras letras dedicou-se ao latim e ao francês, bem como à música, estudando flauta, piano e órgão.

Aos 20 anos de idade pretendeu fazer-se médico, depois engenheiro e acabou bacharel em Direito. Segundo Mucio Leão, "Simultaneamente com essas tentativas de encontrar uma vocação e uma carreira, ia-se entregando a outras atividades, mais de acordo com o seu espírito: continuava a estudar arquitetura, pintura e música, os vários ramos da literatura, e, sobretudo filologia" (LEÃO, 1954, p.14).

Casou-se em 1889 com Maria Luiza da Fonseca Ramos, sempre referida por Leão como D. Nhã-Nhã. Tal como ele, a esposa provinha de família simples. Seu pai era professor da Escola Normal no Rio de Janeiro. Foram 45 anos de convivência e 16 filhos, dos quais apenas oito sobreviveram. Pelo elevado índice de mortalidade dos filhos é possível abrir as cortinas das tragédias vividas por João Ribeiro e pouco mencionadas pelos seus biógrafos. Elas aparecem em confidências dolorosas ao amigo José Lino, e junto delas, os respingos das dificuldades financeiras. 
Após fixar-se, no Rio de Janeiro, mandou buscar mãe, irmã e avô para viverem consigo. Em entrevista publicada em $O$ Jornal de janeiro de 1934 e parcialmente reproduzida em 9 mil dias com João Ribeiro, a mãe do intelectual, D. Guilhermina Roa Ribeiro, destaca que o primogênito da família se chamava Julio Cesar Ribeiro. Morrera no Paraná, aos 25 anos de idade. João aparece na memória da velha senhora de 94 anos de idade como um menino que sempre se dedicou aos estudos. Em sua memória, seleciona os momentos em que ele vivia entulhado no quarto, debruçado sobre os livros. Julio é apresentado como seu contrário, "gênio alegre, brincalhão, tinha sempre um 'a propósito' para fazer florir o sorriso nas rodas onde estivesse” (RIBEIRO, 1934, p. 148).

$\mathrm{Na}$ mesma entrevista, a velha senhora deixa escapar a existência de uma filha: "[João Ribeiro] Detestava as visitas das amiguinhas de sua irmã Neréa, às quais não permitia que entrassem em seu quarto" (RIBEIRO, 1934, p. 152). Em suas notas biográficas, Mucio Leão não faz nenhuma referência à existência das irmãs de João Ribeiro. Além disso, ao nomear os oito filhos, da lista dos 16 gestados por D. Nhã-Nhã, faz questão de indicar, no caso das mulheres, seus respectivos maridos: "Betty, casada com Rodolfo Sinigália Xavier [...], Ema, casada com Gerson Acioli; e Xavieva (sic), que se conservava solteira”. Quanto aos homens, o mais importante era destacar sua ocupação profissional: “João, funcionário da Central do Brasil; Manuel, funcionário da Sul América; Joaquim, fiscal do ensino; e Antônio João, estudante de veterinária” (LEÃO, 1954, p. 23).

O lapso parece ser compartilhado por João Ribeiro. Em correspondência a José Lino, anuncia o casamento de uma irmã. A forma como a notícia é revelada evidencia o hiato que separa a sensibilidade daquele período em relação a este. O casamento é comentado de forma ligeira, pois o destaque é dado para a profissão do noivo e a redução das despesas: "não só o casamento é muito do meu agrado, como também com isso, eu melhoro muito de condições, pois a nossa família ficará muito menor". ${ }^{29} \mathrm{Na}$ mesma carta sublinha "Parece que pela reforma da Biblioteca eu terei aumento de ordenado, o que não é mau".30

No ano seguinte já está mais otimista quanto ao "ordenado". Sua nomeação para professor no Pedro II é comunicada ao amigo, antes pela melhoria financeira que proporcionaria que pelo status social que o oficio conferia: "Passei para o Ginásio Nacional como lente de história. Estou agora melhor, ganho mais e disponho de mais tempo". ${ }^{31}$ Diante da situação, faz planos para as férias: "Eu estou com vontade de dar um pulo até Vassouras em fevereiro e talvez vá até a Paraíba". ${ }^{32}$ Parece estar em fase produtiva no trabalho. Faz "bicos" como jornalista, "Escrevo sempre no Paiz, nos domingos e também escrevo no Correio do Povo", além de traduções: "estou traduzindo um livro italiano muito interessante, daqui a uns 3 ou 4 meses, ficará pronto". ${ }^{33}$

Nessa carta anuncia a chegada de mais um rebento: "Participo-te que tenho mais uma filhinha. Chama-se Emma, e está muito gordinha e sadia". ${ }^{34}$ Os bons ventos profissionais e o 
nascimento da filha esmorecem a perda que tivera recentemente: "Como já sabes, o meu filhinho morreu e eu espero que esta viva para ser mais um motivo de alegria em minha casa". ${ }^{35} \mathrm{~A}$ naturalidade com que a nota da morte do filho é acrescentada faz pensar sobre as incertezas de sobrevivência de um bebê, no Brasil, no final do século XIX, mesmo que nascido em família com certos recursos financeiros. ${ }^{36}$ Nas despedidas de praxe, como se pede em missiva amistosa, João Ribeiro recomenda lembranças à família do amigo e o convida a visitá-lo no Rio de Janeiro. A espontaneidade com que glorifica o verão carioca nos remete aos problemas que afligiam a cidade, em especial, em tempos de calor: "Tu e D. Olga podiam vir com mais facilidade cá. Não tem havido moléstia nenhuma. O verão está magnífico". ${ }^{37}$

As duas referências destacadas acima - expectativa de vida e moléstia - eram preocupações compartilhadas socialmente no Brasil, em especial, no Rio de Janeiro desse período. Para um sujeito de poucas posses que vinha conquistando espaço na sede política e cultural do País, era algo fundamental. João Ribeiro sequer sabia que, após a bonança profissional, enfrentaria momentos difíceis junto à família.

No ano de 1892, José Lino participa ao amigo o nascimento do segundo filho. No entanto, nenhuma resposta obtém. Em junho do mesmo ano, João Ribeiro justifica seu silêncio:

\begin{abstract}
Não respondi, porque estava atribulado. Minha filhinha Emma tinha adoecido gravemente e para cúmulo de infelicidade, apesar de todos os cuidados e esforços, veio a falecer o pobre anjinho, lançando-me a mim e a minha mulher, nessa dor desesperada e terrível, que pela primeira vez experimentamos perdendo um filho quando ele já estava crescido, criado e era a alegria da casa. Emma morreu. E isso basta para que aqui estejamos todos inconsoláveis. Faleceu no dia 31 de maio. ${ }^{38}$
\end{abstract}

Diante do acontecimento, a cidade do Rio de Janeiro e a vida profissional são vistas pela lente da dor. Nesse momento, não depositava muita expectativa sequer na chegada da outra filha, nascida no intervalo verificado entre a primeira e segunda missiva indicadas acima, ou seja, entre outubro de 1890 e junho de 1892.

Antes, poucos dias, a 20 de abril nasceu outra filhinha minha, a que dei o nome de Xavieria. ${ }^{39}$ Mas, na verdade, não tenho mais coração para alegrar-me; a imagem de Emma me tortura o espírito e hoje o digo [...]. É uma dor insuportável e a maior de quantas dores possam afligir o espírito humano. Vê tu como sou desgraçado e infeliz. $^{40}$

O amigo esperava as felicitações pelo nascimento do segundo filho. João Ribeiro não deixa de cumprimentá-lo, mas na saudação o artífice da palavra é traído pela matéria que melhor sabe manejar, as letras. Isso porque, em determinado momento da correspondência, desabafa: "não sei se há felicidade em ter-se filhos". ${ }^{41}$ Nada mais infeliz de se dizer a alguém que buscava dividir a 
alegria do novo rebento. A frase final de João Ribeiro não deixa de ser menos dramática: "não quero dizer-te mais nada. Adeus". 42

Passado pouco mais de dez dias, nova carta de João Ribeiro. Este parabeniza José Lino pelo batizado do pequeno Antonio. Ante o convite de passar o São João com o amigo, ressalta: "Eu e minha mulher temos ainda o espírito atribulado pela morte de Emma", no que acrescenta: "Demais, Xavieria ainda está muito pequenina e não podemos leva-la nem deixa-la aqui". ${ }^{43}$ Nenhuma expectativa ou alegria é manifestada em relação à criança. Com dois filhos mortos em curto prazo, o futuro de Xavieria ficava em suspenso.

Quanto à sugestão feita pelo amigo para que saísse do Rio de Janeiro, sua resposta mantémse coerente com as preocupações financeiras: "Quanto ao que me aconselhas de deixar o Rio de Janeiro, isso é melhor de pensar do que de fazer. Em parte nenhuma do Brasil eu teria a colocação que aqui tenho". 44

Como bem revelou, anos mais tarde, na entrevista concedida a João do Rio, em fragmento reproduzido acima, suas "expansões" não eram de colocar em risco o conforto adquirido. É o que expressa de forma racional, malgrado o sofrimento da morte da filhinha, havia pouco mais de 20 dias: "eu não devo abandonar o que consegui com esforço, para principiar de novo a vida". 45 chama da dor e da incerteza anunciada na carta anterior quanto à sobrevivência dos filhos permanece acessa, embora em chamas menos agitadas: Aqui se morre, é verdade; mas em toda a parte se morre igualmente". 46

Em 1893, a morte aparece novamente na correspondência com o amigo: "Como sabes o Rio está em revolução. Mas o pior é que tenho a minha mulher doente; teve ela um aborto e ainda se acha de cama". ${ }^{47}$ A notícia da perda é dada de raspão. As perspectivas de recuperação da esposa parecem promissoras "[Nhã-Nhã] já vai melhor e deve ficar boa, dentro de poucos dias". ${ }^{4}$ Preocupa-o a situação política do momento. Ainda que a convalescência da esposa seja apontada como "pior", a notícia da revolução é anunciada antes de sua condição. O descuido deve ser creditado ao clima conturbado, vivido na capital da República naquele momento. Os canhões da marinha brasileira estavam apontados para a cidade no episódio que ficou registrado nos anais historiográficos como Revolta da Armada (TOPIK, 2009). A tensão instaurada pelo movimento que tinha entre suas metas derrubar o governo de Floriano Peixoto estendia seus tentáculos para além da esfera política. João Ribeiro acrescenta: "Não sei o que farei se a cidade for bombardeada, talvez tenha de sair para fora (sic), para qualquer subúrbio, longe das balas. O caso aqui está muito feio e tem morrido já muita gente, se bem que os jornais nada publiquem". ${ }^{4}$

Mucio Leão deixa escapar em breve registro que tem como objetivo evocar a paixão de Ribeiro pela Alemanha e pela Itália e outras perdas na família. "Milão, sobretudo, fala à sua alma e à sua saudade. Ali morre, em 1896, seu filhinho, o seu pequeno Neco. É sob uma lápide do Campo 
Santo da cidade ilustre, não longe da 'Ceia' de Da Vinci, que o seu pequenino ficou a dormir os dias eternos" (LEAO, 1962, p. 24).

No parágrafo seguinte do mesmo texto, registra a perda de mais uma filha:

Depois, regressa à Alemanha, vai fixar-se no Hanover. Ali, nasce-lhe Vera Xênia. É um encanto para o seu lar, essa alemãzinha, que vem povoá-lo de uma graça nova. Mas Vera Xênia vive pouco. E João Ribeiro tem a amargura de deixá-la no Campo Santo de Hanover. Triste, retorna ao Brasil." (LEÃO, 1962, p. 24).

João Ribeiro regressaria à Europa mais duas vezes, em 1901, em rápida incursão oficial, e em 1913, na expectativa de fixar-se por longo tempo. Com tantas perdas, melhor contabilizar os sucessos. Quem sabe essa ideia tenha pesado na construção que seus biógrafos fizeram de sua trajetória. Talvez não tenham se dado conta de que, ao limpar a dor, aparar as arestas do cotidiano familiar e sentimental para evidenciar o intelectual, estavam ao mesmo tempo deixando pistas sobre como se fabrica um imortal. Por sorte, também não se deram conta de que em suas composições deixaram rastros por onde outros pesquisadores poderiam catar novas pistas e traçar outras faces de João.

É possível que, para além de fatores subjetivos, tenham pesado na construção das biografias de Mucio Leão e Joaquim Ribeiro questões singulares ao próprio tempo de suas respectivas produções. Pois não deve ter sido o acaso que orientou Joaquim a construir o perfil de um intelectual cheio de gracejos, em oposição ao semblante amargurado e gênio voluntarioso pintado pela sua geração. Na década de 1930 urgia fixar a imagem do homem irreverente e bem humorado. Em 1960 buscava-se prolongar a memória do intelectual, do acadêmico, do homem que soube reconhecer os modernistas e possuía uma formação universal.

De acordo com Rodrigues (2011), recentemente os historiadores retomaram os estudos sobre João Ribeiro. É o que se verifica nas pesquisas de Hansen (2000), Bandeira de Melo (2008), Silva (2008), Magalhães (2011) e outros analisados pelo pesquisador. Que joão emergirá dessa redescoberta do intelectual sergipano? Ao que parece, a tendência é revisitar seus procedimentos de pesquisa e destacar seu diálogo com as linhas de força da produção historiográfica da época. O joão professor e historiador tem se sobreposto ao joão pai, ensaísta, folclorista e pintor. São escolhas importantes que revelam a distância com os primeiros biógrafos. Elas iluminam novas faces do intelectual. Diante desse quadro que se esboça, difícil não retomar a crônica de Humberto de Campos e com ele repetir: viva a São João! 


\section{Referências bibliográficas}

ARAÚJo, Rosa Maria Barboza de. A vocação do prazer: a cidade e a família no Rio de Janeiro republicano. Rio de Janeiro: Rocco, 1993.

CALDAS, Karina Ribiero. Nação, memória e história. A formação das tradições nos manuais escolares (1900-1922). 2005. Dissertação (Mestrado em História). Universidade Federal de Goiás, Goiânia, 2005.

COSTA, Marcos de Farias. João Ribeiro: bibliografia anotada e comentada. Maceió: M. F. Costa, 1998.

DUTRA, Eliana de Freitas. Rebeldes literários da República: história e identidade nacional no Almanaque Brasileiro Garnier (1903-1914). Belo Horizonte: UFMG, 2005.

FRANZINI, Fábio. À sombra das palmeiras: a coleção Documentos Brasileiros e as transformações da historiografia nacional (1936-1959). Rio de Janeiro: Edições Casa de Rui Barbosa, 2010.

GOMES, Angela de Castro. História e historiadores. Rio de Janeiro: FGV, 1996.

GONÇALVES, Marcia de Almeida. Em tempos de epidemia biográfica: Octavio Tarquinio de Souza e sua busca por homens históricos. In: NEVES, Lucia Maria Bastos Pereira das... [et al.] (org.). Estudos de historiografia brasileira. Rio de Janeiro: FGV, 2011.

HALBWACHS, Maurice. A memória coletiva. São Paulo: Centauro, 2006.

HANSEN, Patricia. Feições e fisionomia. A História do Brasil de João Ribeiro. Rio de Janeiro: Access, 2000.

LEÃO, Múcio (org.) João Ribeiro. Crítica: clássicos e românticos brasileiros. Rio de Janeiro: Publicações da Academia Brasileira de Letras, 1952.

LEÃO, Múcio. João Ribeiro. Rio de Janeiro: Livraria São José, 1962.

LEÃO, Múcio. João Ribeiro: ensaio biobibliográfico. Rio de Janeiro: Publicações da Academia Brasileira de Letras, 1954.

LEÃO, Múcio. João Ribeiro: trechos escolhidos. Rio de Janeiro: Agir, 1960.

LEVILLAIN, Philippe. Os protagonistas: a biografia. In: RÉMOND, René (org.). Por uma história política. Rio de Janeiro: UFRJ/FGV, 1996.

LORIGA, Sabina. O pequeno X: da biografia à história. Belo Horizonte: Autêntica, 2011.

MAGALHÃES, Marcelo de Souza. A construção de um cânone republicano: a escrita da história escolar na virada do século XIX para o XX. In: Anais do XXVI Simpósio Nacional de História ANPUH. São Paulo, 2011. Disponível em: http://www.snh2011.anpuh.org/resources/anais/14/1308166282_ARQUIVO_Anpuh2011textoMarceloMagalhaesrevisto.pdf Acesso em 6 jun 2012. 
MELO, Ciro Flavio de Castro Bandeira de. Senhores da história e do esquecimento. Belo Horizonte: Argvmentum, 2008.

NEVES, Lucia Maria Bastos Pereira das. A biografia de D. João VI: implicações teóricas e metodológicas. In: NEVES, Lucia Maria Bastos Pereira das... [et al.] (org.). Estudos de historiografia brasileira. Rio de Janeiro: FGV, 2011.

OLIVEIRA, Lucia Lippi. A questão nacional na Primeira República. São Paulo: Brasiliense, 1990.

RIBEIRO, João. Cartas devolvidas. 2. ed. Rio de Janeiro: Livraria São José, 1960.

RIBEIRO, João. História do Brasil: curso superior. 18ª ed. Rio de Janeiro: Francisco Alves, 1964.

RIBEIRO, Joaquim. A posição doutrinária de João Ribeiro na historiografia nacional. In:

História do Brasil: curso superior. 18. ed. Rio de Janeiro: Francisco Alves, 1964.

RIBEIRO, Joaquim. Estética da língua portuguesa. 2. ed. Rio de Janeiro: J. Ozon, 1964.

RIBEIRO, Joaquim. 9 mil dias com João Ribeiro. Rio de Janeiro: Record, 1934.

RIO, João do. O momento literário. Rio de Janeiro: Fundação Biblioteca Nacional/Departamento Nacional do Livro, 1994.

RODRIGUES, José Honório (org.). Correspondências de Capistrano de Abreu. 2. Ed. Rio de Janeiro: Civilização Brasileira, v. 3, 1977.

RODRIGUES, Renata Conceição Lopes. Mãe de família: discurso profilático contra a sífilis, Rio de Janeiro, 1878-1889. 2004. Dissertação (Mestrado) - Escola Nacional de Saúde Pública. Fundação Oswaldo Cruz, Rio de Janeiro, 2004.

RODRIGUES, Rogério Rosa. João Ribeiro e a historiografia brasileira: percursos e perspectivas. Caderno de resumos \& Anais do $5^{\circ}$. Seminário Nacional de História da Historiografia: biografia \& história intelectual. Ouro Preto: EdUFOP, 2011.(ISBN: 978-85-288-0275-7). Disponível em: http://www.seminariodehistoria.ufop.br/ocs/index.php/snhh/2011/paper/viewFile/955/366. Acesso a 08 dez 2011.

SCHMIDT, Benito Bisso. Construindo biografias... historiadores e jornalistas: aproximações e afastamentos. Estudos Históricos. Rio de Janeiro, FGV/CPDOC, n. 19, 1997, p. 3-21.

SILVA, Roberto Cândido da. O polígrafo interessado. João Ribeiro e a construção da brasilidade. 2008. Dissertação (Mestrado em História). FFLCH/USP. São Paulo, 2008.

TOPIK, Steven C. Comércio e canhoneiras: Brasil e Estados Unidos na Era dos Impérios. São Paulo: Companhia das Letras, 2009.

VENTURA, Roberto. Estilo tropical: história cultural e polêmicas literárias no Brasil. São Paulo: Companhia das Letras, 1991. 


\section{Notas}

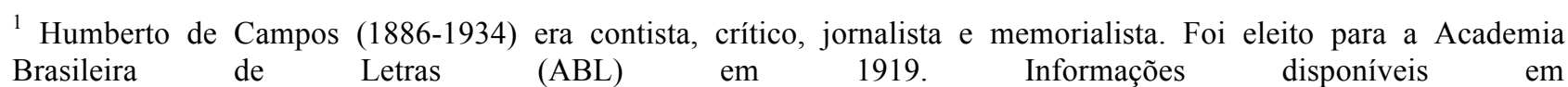
http://www.academia.org.br/abl/cgi/cgilua.exe/sys/start.htm?infoid=640\&sid=221 Acesso em 6 jun 2012.

${ }^{2}$ A crônica foi publicada no "Diário Carioca" em 24/06/1933 e reproduzida integralmente no livro de Joaquim Ribeiro (1934, p. 23-29).

${ }^{3}$ Crônica publicada no "Jornal do Brasil” em 26/06/1928 e reproduzida em Mucio Leão (1954, p. 7-8)

${ }^{4}$ As informações sobre a trajetória pessoal de João Ribeiro foram recolhidas de Mucio Leão (1954), de Marcos de Farias Costa (1998) e do site da Academia Brasileira de Letras disponível em http://www.academia.org.br/abl/cgi/cgilua.exe/sys/start.htm?sid=293. Acesso em 6 jun 2012.

${ }^{5}$ Trata-se dos livros Gramática Portuguesa ( $1^{\circ}$ ano), 136 páginas, Editora Alves e Cia. 1886; Gramática Portuguesa, curso médio ( $2^{\circ}$ ano), 244 páginas, Editora Alves e Cia. 1887 e Gramática Portuguesa, curso superior ( $3^{\circ}$ ano), 499 páginas, Editora Alves e Cia. 1887. Informações recolhidas de Mucio Leão (1960).

${ }^{6}$ Para Eliana de Freitas Dutra sob a direção de João Ribeiro o almanaque acentuou seu caráter nacionalista e enciclopédico (DUTRA, 2005, p. 34).

${ }^{7}$ Todas as informações sobre vida e obra de João Ribeiro retiradas de Leão (1954).

${ }^{8}$ Vale ressaltar que na relação dos títulos publicados pela coleção "Documentos Brasileiros", levantada por Fabio Franzini, consta o livro "Folclore dos Bandeirantes" de Joaquim Ribeiro, volume 53 publicado em 1946 (FRANZINI, 2010, p. 305).

${ }^{9}$ Os créditos biográficos de Joaquim Ribeiro foram recolhidos da apresentação feita no livro Estética da Língua Portuguesa de sua autoria (1964) e de Mucio Leão (1954).

${ }^{10}$ A publicação do livro coincide com os últimos dias de João Ribeiro. O exemplar de que disponho possui autógrafo com data de 9 de fevereiro de 1934. João faleceu no dia 13 de abril do mesmo ano.

${ }^{11}$ Não cabe aqui suposição de que João não tenha sido bom pai, mas tão somente a indicação de que, na seleção dos fatos mais marcantes dos nove mil dias de convívio, não aparece troca de afeto paternal. Nesse sentido, não parece surpreendente que sua primeira memória seja a da preta Preciosa, da biblioteca sombria ou da tela pintada no quintal ensolarado. Para uma análise da sensibilidade para com as crianças no período republicano brasileiro, ver Rosa Maria Barbosa de Araújo. Para ela, no final do século XIX "A nobre função de pai e mãe requeria dedicação, investimento material e afetivo, caracterizando-se a cumplicidade sentimental da família” (ARAÚJO, 1993, p. 166).

${ }^{12}$ Carta de 11/11/1920 de Capistrano de Abreu para João Lucio de Azevedo. Consta na edição de Correspondência de Capistrano de Abreu organizada por José Honório Rodrigues (1977, p. 384-389). Essa impressão aparece também em João do Rio (1994).

${ }^{13}$ A citada correspondência de Capistrano de Abreu para João Lucio de Azevedo começa da seguinte forma "Deixa-me aproveitar este resto de papel para falar um pouco da vida alheia: hoje atiro o lenço ao João Ribeiro" Carta de 11/11/1920 de Capistrano de Abreu para João Lucio de Azevedo In: Rodrigues (1977, p. 385). Com essa declaração, tece comentários pouco elogiosos sobre a personalidade de Ribeiro, embora reconheça seus méritos intelectuais.

${ }^{14}$ Para além de palestras e entrevistas efetuadas após uma década da morte do escritor, o organizador chegou a publicar o plano das obras completas na revista da Academia, v. 67, 1944 (LEAO, 1952, p.7)

${ }^{15}$ Embora o plano completo das obras tenha sido organizado e divulgado por Mucio Leão, o material ainda não foi encontrado no arquivo pessoal de João Ribeiro, tampouco no de Mucio Leão, disponível no Arquivo da ABL.

16 Os créditos biográficos sobre Mucio Leão foram recolhidos do site da ABL e estão disponíveis em http:/www.academia.org.br/abl/cgi/cgilua.exe/sys/start.htm?infoid=475\&sid=222 acesso em 6 de junho de 2012 .

${ }^{17}$ Carta de 04/08/1895 para Lucio de Mendonça. Arquivo da ABL.

${ }^{18}$ Carta de 31/12/1895 para José Lino. Arquivo da ABL.

${ }^{19}$ Carta de 17/01/1900 para Graça Aranha. Arquivo da ABL.

${ }^{20}$ Carta de 17/01/1900 para Graça Aranha. Arquivo da ABL.

${ }^{21}$ Carta de 11/11/1920 de Capistrano de Abreu para João Lucio de Azevedo. Consta na edição de Correspondência de Capistrano de Abreu organizada por José Honório Rodrigues (1977, p. 388).

${ }^{22}$ Carta de 06/06/1900 para Graça Aranha. Arquivo da ABL.

${ }^{23}$ Carta de 06/06/1900 para Graça Aranha. Arquivo da ABL.

${ }^{24}$ Carta de 06/06/1900 para Graça Aranha. Arquivo da ABL.

${ }^{25}$ Carta de 07/06/1900 para Graça Aranha. Arquivo da ABL.

${ }^{26}$ Carta de 07/06/1900 para Graça Aranha. Arquivo da ABL.

${ }^{27}$ Carta de 09/11/1900 para Graça Aranha. Arquivo da ABL.

${ }^{28}$ Carta de 21/05/1903 de Joaquim Nabuco para João Ribeiro. Arquivo da ABL.

${ }^{29}$ Carta de 04/10/1890 para José Lino. Arquivo da ABL.

${ }^{30}$ Carta de 04/10/1890 para José Lino. Arquivo da ABL.

${ }^{31}$ Carta de 01/01/1891 para José Lino. Arquivo da ABL.

${ }^{32}$ Carta de 01/01/1891 para José Lino. Arquivo da ABL.

${ }_{33}$ Carta de 01/01/1891 para José Lino. Arquivo da ABL (grifos originais).

${ }^{34}$ Carta de 01/01/1891 para José Lino. Arquivo da ABL. 


\footnotetext{
${ }^{35}$ Carta de 01/01/1891 para José Lino. Arquivo da ABL (grifos meus).

${ }^{36} \mathrm{O}$ índice de mortalidade infantil na cidade do Rio de Janeiro chamou a atenção dos cientistas durante o século XIX. Renata Conceição Lopes Rodrigues (2004) analisa a questão em sua dissertação de mestrado, defendida na Fiocruz. Uma breve apreciação sobre os cuidados com a criança, bem como acerca da sensibilidade familiar, no período republicano, pode ser encontrada em Rosa Maria Barboza de Araújo (1993).

${ }^{37}$ Carta de 01/01/1891 para José Lino. Arquivo da ABL (grifos meus).

${ }^{38}$ Carta de 08/06/1892 para José Lino. Arquivo da ABL.

${ }^{39}$ De acordo com Capistrano de Abreu, o nome foi dado em homenagem a Tiradentes (RODRIGUES 1977, p. 388). Tal referência confirma o espírito republicano de João Ribeiro, manifestado ao amigo por essa época.

${ }^{40}$ Carta de 08/06/1892 para José Lino. Arquivo da ABL.

${ }^{41}$ Carta de 08/06/1892 para José Lino. Arquivo da ABL.

${ }^{42}$ Carta de 08/06/1892 para José Lino. Arquivo da ABL.

${ }^{43}$ Carta de 21/06/1892 para José Lino. Arquivo da ABL.

${ }^{44}$ Carta de 21/06/1892 para José Lino. Arquivo da ABL.

${ }^{45}$ Carta de 21/06/1892 para José Lino. Arquivo da ABL.

${ }^{46}$ Carta de 21/06/1892 para José Lino. Arquivo da ABL.

${ }^{47}$ Carta de 18/09/1893 para José Lino. Arquivo da ABL.

${ }^{48}$ Carta de 18/09/1893 para José Lino. Arquivo da ABL.

${ }^{49}$ Carta de 18/09/1893 para José Lino. Arquivo da ABL.
}

Recebido em junho/2012.

Aprovado em janeiro/2013. 